DOI 10.37882/2500-3682.2021.12.24

\title{
ЕДИНСТВО ПРИРОДНОГО И КУЛЬТУРНОГО \\ В ЧЕЛОВЕКЕ В УСЛОВИЯХ СОВРЕМЕННЫХ ТРАНСФОРМАЦИОННЫХ ПРОЦЕССОВ ОБЩЕСТВА
}

\section{THE UNITY OF NATURAL AND CULTURAL IN A PERSON IN THE CONTEXT OF MODERN TRANSFORMATIONAL PROCESSES OF SOCIETY}

V. Skopa

Summary: The article deals with the problem of the unity of natural and cultural in man in the context of modern transformational processes of society. Special attention is paid to education as an institution that forms a social personality. Within the framework of the educational environment, everyone creates their own «cultural system». It has been determined that consciousness and morality should act as defining elements of social regulation of people's behavior. The analysis of the doctrines about man allows us to single out several models of the interpretation of human nature: the naturalistic version of understanding the nature of man; evolutionary theory of Darwin; instinctiveism; social version; gene-cultural coevolution and biocultural anthropology. It is revealed that human nature is a single biocultural integrity. The biocultural approach views humans as a biological, social and cultural being. This includes considering biological variability as a function of response and adaptation to the environment in terms of taking into account the needs of the socio-cultural sphere.

Keywords: man, culture-centricity, anthropology, co-evolution, globalization, society.

\author{
Скопа Виталий Александрович \\ Д.и.н., профессор, Алтайский государственный \\ педагогический университет, г. Барнаул \\ sverhtitan@rambler.ru
}

Аннотация: В статье рассматривается проблема единства природного и культурного в человеке в условиях современных трансформационных процессов общества. Отдельное внимание уделено образованию как институту, формирующему социальную личность. В рамках образовательной среды каждый создает свою «систему культуры». Определено, что сознание и мораль должны выступать в качестве определяющих элементов социального регулирования поведения людей. Анализ учений о человеке позволяет выделить несколько моделей трактовки природы человека: натуралистическая версия осмысления природы человека; эволюционная теория Дарвина; инстинктивизм; социальная версия; генно-культурная коэволюция и биокультурная антропология. Раскрыто, что природа человека представляет собой единую биокультурную целостность. Биокультурний подход рассматривает человека как биологическое, социальное и культурное существо. Это включает рассмотрение биологической изменчивости как функции реагирования и адаптации к окружающей среде в условиях учета запросов социально-культурной сферы.

Ключевые слова: человек, культуроцентричность, антропология, коэволюция, глобализация, общество.

развития будущих поколений, так и жизнеспособность, эффективность самого общества и его составляющих элементов. Образование вооружает людей навыками и базовыми знаниями, необходимыми для общества, что, в свою очередь, предоставляет субъектам социальных отношений возможности определять и преследовать свои собственные цели, а также активно участвовать в общественной жизни в качестве полноценных автономных личностей [11].

Обострение экологической ситуации в мире, а также реальная угроза дальнейшего ухудшения ставят проблему сохранения природной среды обитания социума на одно из первых мест в ряду глобальных проблем человечества, выводит проблему на первое место в контексте глобализации образования, взаимодействия социальных институтов - а это почва самосознания гражданина, нации, государства, и наконец, мирового сообщества [16]. Процесс глобализации, получивший сегодня обще- 
мировой масштаб, порождает новые противоречивые последствия. Отсюда становится очевидным, что человечество нуждается в новой парадигме, касающаяся отношений между народами и государствами, новой геополитической конструкции мироздания, безопасной для всего мира и составляющих его частей [12].

Своеобразие социумов сказывается на отношении к многочисленным проблемам - правам человека, политическим режимам, торговли, образования, охраны окружающей среды. В рамках образовательной среды каждый создает свою «систему культуры», которая может столкнуться с другими, непонятными ей системами. Отсюда становится очевидным, что межцивилизационная проблематика превращается в проблематику человеческих отношений [8]. Односторонность во взглядах на человека, а это касается биологического и социологического подходов, в частности, в образовательном когнитивном пространстве, привела к формированию в XX веке идеи отсутствия субстанциального закрепления бытия человека. Исходя из этого формируется концепция новой плюралистической идентичности, что отражено в исследовании Т. Даниловой и закреплено следующим образом «человечество все больше испытывает влияние со стороны сил, которые являются не вполне рациональными, и предпочитают миф над историей, религию над наукой, циклическое временя над линейным» [1]. Таким образом, фрагментация общества в сочетании с возрождением интереса к коллективной идентичности, мифа, религии и циклического времени требуют идеи, сложной и глубокой, чем просто «Смерть собственного Я». Они требуют осознания возрождения плюралистической самости, множественного «Я» [2]. Однако человек, как и раньше, остается предметным, материальным существом, живущим в созданном его мире культуры, вследствие чего природа человека требует другого, более широкого понимания. Становится очевидным, что влияние деятельности людей на окружающую среду не просто превращается в фактор, определяющий его эволюцию, но и растет настолько быстро, что говорить о любом равновесии биосферы и одновременно о сохранении гомеостаза вида «homo sapiens» уже не представляется возможным [6].

Сегодня, в образовательном процессе каждого государства, тема природы человека получает новое звучание благодаря синтезу многовековых философских традиций в осмыслении человека и комплекса современных обществоведческих наук, а также благодаря развитию новых наук о поведении высших животных, биология которых наиболее подобна биологии человека. Кроме того, основательного мультидисциплинарного исследования требуют современные биотехнологии и психотехнологии, которые могут быть использованы для изменения человеческой природы - основы при реализации процессов глобализации социальных институтов.
Главной задачей образования в проблемном поле ее глобализационных подходов ныне - необходимость создания новой научной парадигмы, которая целостно отражает специфику природы человека, его причастность и к миру природы, и к миру культуры, характеризующие человека в качестве самостоятельной формы бытия [9].

Проблема природы человека на протяжении веков исследовалась представителями разных временных эпох - Античность (Платон, Аристотель); Средневековье (А. Блаженный, Ф. Аквинский); Новое время (Т. Гоббс, Р. Декарт). В период XVIII-XIX столетий процесс познания человека усиливается посредством различных концептуальных подходов и представлен отдельными работами К. Маркса, Ф. Ницше, А. Шопенгауэра, 3. Фрейда, Э. Фромма. Значительный вклад в осмысление природы человека сделали К. Юнг, А. Адлер, Э. Кассирер, В. Виндельбанд, Г. Риккерт, М. Бахтин, А.Ф. Лосев, Ю. Лотман.

Благодаря многочисленным исследованиям мировое сообщество начинает осознавать, что моральные принципы и поведение людей в биосфере больше не соответствуют тем условиям жизни, в которые пребывает общество. Наступает осознание того, что только коэволюция с биосферой позволит всему человечеству разумно вписаться в природные циклы, подняться к пониманию универсальных законов, которые царят в мире [10]. Подобные тенденции выводят на первый план научного поиска вопрос, который касается безопасного развития цивилизации, образования человека, как социальной категории, а также его воздействие на окружающую действительность.

Сознание и мораль, которые осуществляют свою регулятивную функцию посредством наделения человеческой деятельности правовым и духовно-нравственным содержанием, должны выступать в качестве определяющих элементов социального регулирования поведения людей. Таким образом, общество встало перед фактом: необходимо научиться управлять собой и соотносить свои действия с природными возможностями, тем самым обеспечив такое взаимодействие с окружающей средой, которая позволит гармонично развиваться всей социоприродной целостности.

Для своего экологического выживания человечество должно разработать и активно реализовывать единую глобальную стратегию общемирового развития на почве общемирового сотрудничества в образовании, что обеспечит качество окружающей среды для цивилизации XXI века. Исходя из этого встал вопрос о формировании более широкой экологизации общественного сознания, которая включает в себя развитие экологического сознания как самостоятельной формы общественного, а также внесение экологического аспекта в другие формы и уровни общественного сознания - как элемент подсистемы. 
Потребность в формировании экологической культуры как решающего фактора в гармонизации отношений общества и природы становится в наше время все более актуальной проблемой, особенно в глобализационных процессах трансформации образования. Осознание всей сложности социоприродной ситуации существенно зависит от уровня нравственных ценностей, степени образованности человека, культурного развития $[4,13$, 14]. Мировоззрение, определяя ценностные ориентации бытия, интересы человека и общества в целом, влияет не только на систему нравственных ценностей и ориентиров, но и обусловливает развитие представлений об идеальном, приводит стратегию развития социума.

Поскольку разные народности различно воспринимают естественные ограничения, приоритетным при решении экологических проблем должен стать пересмотр ценностной иерархии в общественном сознании и во всех сферах социальной жизни, особенно в образовательном пространстве.

Анализ учений о человеке позволяет выделить несколько моделей трактовки природы человека, сложившихся в философской, физической, биологической, культурной антропологии и по-разному оценивать степень единения человека с миром природы и культуры. Натуралистическая версия осмысления природы человека предполагает ее укорененность именно в природе. Философия природы рассматривается как целостная система общих законов естествознания. В различных аспектах идея биологической природы человека разрабатывалась на протяжении всей истории философской и научной мысли. В разные времена природу человека сводили к телу страстей и влечений, инстинктов и пытались обосновать естественное происхождение морали, разумности и социальности человека. В XIX веке эволюционная теория Дарвина становится естественно-научным обоснованием биологического представления о человеке. В предельном случае этот подход приводит к отождествлению биологии высших животных и биологии человека в инстинктивизм. В классическом облике инстинктивизм был сформулирован в начале XX века шотландским психологом и социологом Макдугаллом [5]. Представители данного направления исследуют филогенетические корни поведения людей, истоки которых сводятся к сознательному. Социальная версия природы человека основывается на признании общих социальных установок, присущих всем индивидам. Согласно сути данного подхода, сущность человека не может быть выведена из биологии человека, следовательно, особенности человека как социокультурного существа представляют собой интериоризированные общественные отношения. Эта модель природы человека разрывает филогенетическую преемственность животного мира и человека, поскольку считается, что социализации подверглись все стороны биологии человека и в человеке не осталось ничего от животного [8]. Теория генно-культурной коэволюции и биокультурная антропология утверждают, что человек органично вплетен как в мир природы, так и в мир культуры. Его потребности, тело, психика, поведение имеют хотя и окультуренную, но биологическую базу, возникшую эволюционным путем.

Своеобразная попытка синтеза биологического и социального в человеке была сделана представителями социобиологии, которые утверждают, что типы социального поведения человека имеют биологическое происхождение. Социобиологическая теория основывается на теории генно-культурной коэволюции. Эта теория описывает сложные взаимодействия, в результате которых культура генерируется и оформляется биологическими императивами, одновременно в генетической эволюции в ответ на культурные нововведения меняются биологические свойства [3]. По мнению американских обществоведов Ч. Ламсдена и Э. Уилсона, генно-культурная коэволюция одна и без посторонней помощи создала человека $[4,5]$. В свою очередь японский ученый И. Масуда подробнее описывает теорию генно-культурной коэволюции, показывая, как поступки животных односторонне определяются генами, а человек создает культуру на основе действия мозга и умственных способностей. Биокультурную трактовка «Homo sapiens» разработал Э. Фромм, который стремился к всестороннему рассмотрению биологических, социальных и экзистенциальных аспектов бытия человека. С одной стороны, по Э. Фромму, человек представляет собой один из биологических видов, а с другой - ему присущи специфические свойства (разум, самосознание, воображение), отличающие его от животных и связанные с его социальной жизнью [15].

Итак, природа человека представляет собой единую биокультурную целостность, «человеческая натура - это не сумма врожденных, биологически закрепленных побуждений, но и не мертвый слепок с матрицы социальных условий». Если социобиология ищет источник, мотивы человеческого поведения, исходя из биологической подоплеки существования человека, то биокультурная антропология пытается понять, как культура влияет на наши биологические возможности и ограничения. Культура превратилась в важный аспект нашей окружающей действительности за последние несколько тысяч лет, и ее значение продолжает расти быстрыми темпами.

Биокультурний подход рассматривает человека как биологическое, социальное и культурное существо. Это включает рассмотрение биологической изменчивости как функции реагирования и адаптации к окружающей среде в условиях учета запросов социально-культурной среды $[3,8]$. Значение биокультурного подхода заключается в создании модели для понимания динамики взаимодействия между человеческими биологически- 
ми, психологическими и социально-культурными особенностями в ответ на изменения окружающей среды. Антропологи всего мира сегодня делают акцент на необходимости большей интеграции культурной и биологической антропологии. Биокультурний подход обеспечивает базовую основу для преодоления разрыва между культурной и биологической антропологией, тем самым описывая истинную природу антропологии как научной дисциплины.

Таким образом, в рамках очерченной парадигмы человек находится на пересечении мира природы и мира культуры. Человек выступает связующим звеном, а человеческое начало определяется одновременно двумя составляющими - биологической и культурной, при этом ни одна из них не превалирует. Биологическое и культурное в человеке не находятся в иерархической зависимости, а пересекаются, создавая предельное биокультурное начало. Становится очевидным, что специфика формирования экологического сознания в проблемном поле глобализации предопределяет представления о той существенной роли, которую во всех процессах и явлениях объективной реальности играет информационное взаимодействие.

\section{ЛИТЕРАТУРА}

1. Danylova T. Approaching the East: Briefly on Japanese Value Orientations // Research Revolution. International Journal of Social Science \& Management. - Vol. II. Issue 8. 2014 - P. 4-7.

2. Danylova T. Overcoming the Cultural Differences: Parable as a Means of Intercultural Dialogue // Антропологические измерения философских исследований. Вып. 3. 2013 - C. 42-51.

3. Kelso J. Principles of Biocultural Anthropology: URL http://spot.colorado.edu/ kelso/Biologicalanth.html (дата обращения 15.10.2021)

4. McElroy A. Bio-cultural models in studies of human health and adaptation // Medical Anthropology Quarterly. 1990. Vol. 4. - P. 243-265.

5. Szathmáry E. J. E. A view on the science: Physical anthropology at the millennium // American Journal of Physical Anthropology. 2000. 111. - P. 149-151.

6. Антропологические измерения философских исследований. Вып. 7. 2015. - С. 28-35.

7. Бакач Н.Б. Культурная парадигма как объект социально-философского анализа. Автореф. дисс. ... к.ф.н. Волгоград, 1998.

8. Данилова Т.В. Проблема человеческой идентичности в постмодернистской картине мира // Антропологические измерения философских исследований. Сборник научных трудов. Днепропетровск, 2012. - С. 16-22.

9. Демин А.И. Парадигма дуализма: Пространство - время, информация - энергия. М., 2007. - 195 с.

10. Коваленко Е.М. Когнитивная теория культуры в контексте информационного подхода // Международный журнал прикладных и фундаментальных исследований. 2015. № 12-4. С. 741-744.

11. Кондаков И.В. Самосознание культуры на рубеже тысячелетий // Общественные науки и современность. 2001. № 4. С. 138-147.

12. Пелипенко А.А. Смыслогенетический подход // Вопросы социальной теории. 2009. Т. ІІІ. Вып. 1(3). С. 318-339.

13. Порус В.Н. Онтология культуры В.С. Соловьева // Соловьевские исследования. 2009. Вып. 3 (23) С. 4-13

14. Токарев С.А. Ранние формы религии. М., 1990. - 247 с.

15. Фромм Э. Бегство от свободы. М., 1980. - 272 с.

16. Штеренберг М.И. Синергетическое понимание и системные программы эволюции // Сборник Научно технической информации РАН. Сер. 2. 2014. № 6. C. 1-11.

(c) Скопа Виталий Александрович (sverhtitan@rambler.ru). 